\title{
DAMPAK PENGELOLAAN KELAS YANG EFEKTIF \\ BAGI KEBERHASILAN KEGIATAN BELAJAR-MENGAJAR \\ GURU PENDIDIKAN AGAMA KRISTEN MASA KINI
}

Oleh: Ramses Simanjuntak, M.Pd.K ${ }^{1}$

\begin{abstract}
Teachers have an enormous share of the success of learning in school. Teachers play a role helping the development of learners to achieve their goals optimally. In the classroom teachers carry out two main activities namely teaching and learning activities and management of the class.Classroom management is not just a classroom setting, physical facilities and routines, but also managing the various things covered in the learning component. Classroom management activities are intended to create and maintain a conducive classroom atmosphere. So that the process of teaching and learning can take effectively and efficiently. Effective means achieving goals in accordance the precisely designed of plan. Efesin is the achievement of learning objectivesas planned more quickly.
\end{abstract}

Keywords : Teacher, classroom management, learning, efficiently, effectively

\section{Pendahuluan}

\footnotetext{
${ }^{1}$ Penulis adalah Ketua Prodi Pendidikan Agama Kristen di STT Nazarene Indonesia
} 
Sumber daya yang berkualitas merupakan hal yang penting bagi suatu Negara untuk menjadi Negara maju, kuat, makmur dan sejahtera. Upaya peningkatan kualitas sumber daya manusia tidak bisa terpisah dengan masalah pendidikan bangsa.

Untuk itu, dalam penulisan jurnal yang berjudul "Dampak Pengelolaan Kelas Yang Efektif Bagi Keberhasilan Kegiatan Belajar-Mengajar Guru Pendidikan Agama Kristen Masa Kini," maka penulis mencoba untuk mengetengahkan fakta-fakta yang valid dan aktual tentang pengelolaan kelas yang efektif dan dampaknya terhadap kegiatan belajar-mengajar guru Pendidikan Agama Kristen (yang selanjutnya disingkat PAK) masa kini. Jurnal ini berfaedah sebagai karya ilmiah untuk memberikan kontribusi bagi banyak orang, khususnya guru agama Kristen.

Guru memiliki andil yang sangat besar terhadap keberhasilan pembelajaran di sekolah. Guru sangat berperan dalam membantu perkembangan peserta didik untuk mencapai tujuan hidupnya secara optimal. Di dalam kelas guru melaksanakan dua kegiatan pokok yaitu kegiatan belajar mengajar dan pengelolaan kelas.

Kegiatan mengajar pada hakikatnya adalah proses mengatur dan mengorganisasi lingkungan yang ada di sekitar siswa. Semua komponen pengajaran yang meliputi tujuan, bahan pelajaran, kegiatan belajar mengajar, metode, alat dan sumber, serta evaluasi diperankan secara optimal guna mencapai tujuan pengajaran yang telah ditetapkan sebelum pengajaran dilaksanakan. $^{2}$

Jadi pengelolaan kelas tidak hanya berupa pengaturan kelas, fasilitas fisik dan rutinitas, melainkan juga mengelola berbagai hal yang tercakup dalam kompnen pembelajaran. Kegiatan pengelolaan kelas dimaksudkan untuk menciptakan dan mempertahankan suasana dan kondisi

\footnotetext{
${ }^{2}$ Ketut Arya Sunu, I Gusti,Manajemen Kelas, (Yogyakarta: Penerbit Media Akademi, 2015), 10
} 
kelas yang kondusif. Sehingga proses belajar mengajar dapat berlangsung secara efektif dan efesien. Efektif berarti tercapainya tujuan sesuai dengan perencanaan yang dibuat secara tepat. Efesin adalah pencapaian tujuan pembelajaran sebagaimana yang direncanakan dengan lebih cepat.

Kedua tujuan ini harus dicapai dalam kelas, karena di kelaslah segala aspek pembelajaran bertemu dan berproses. Pembelajar dengan segala kemampuannya, pembelajar dengan segala latar belakang dan sifat-sifat individualnya. Kurikulum dengan segala komponennya, dan materi serta sumber pelajaran dengan segala pokok bahasanya bertemu dan bepadu serta berinteraksi di kelas. Bahkan hasil dari pendidikan secara keseluruhan sangat ditentukan oleh apa yang terjadi di kelas. Oleh sebab itu sudah selakyaknya kelas dikelola dengan baik, profesional, dan harus terus-menerus dalam perbaikan (continoues improvment). ${ }^{3}$

\section{Pengertian Pengelolaan Kelas}

Pengelolaan kelas merupakan gabungan dari dua kata yaitu kata pengelolaan dan kata kelas. Pengelolaan dalam bahasa Inggris diistilahkan sebagai Management, itu berarti istilah pengelolaan identik dengan manajement. Pengertian pengelolaan pada umumnya yaitu kegiatan-kegiatan meliputi perencanaan, pengorganisasian, pengarahan, pengkoordinasian, pengawasan, dan penilaian. ${ }^{4}$

Sedangkan definisi kelas adalah suatu kelompok orang yang melakukan kegiatan belajar bersama yang mendapat pembelajaran dan pembelajar. ${ }^{5}$ Sementara Ahmad Djauzak dalam bukunyayang berjudul: "Pedoman Pembinaan Profesional Guru Sekolah

\footnotetext{
${ }^{3}$ Hamalik, Oemar, Manajemen Pendidikan dan Pelatihan, (Bandung: Penerbit Y.P Pemindo, 2000), 37

${ }^{4}$ Imam Azhar, Pengelolaan Kelas Dari Teoritis Ke Praktis, (Yogyakarta: Penerbit Insyira, 2013), 15

${ }^{5}$ Hamalik, Oemar. Manajemen Pendidikan dan Pelatihan, (Bandung: Penerbit Y.P Pemindo, 2000), 38
} 
Dasar"mengatakan kelas ialah ruangan belajar dan atau rombongan belajar. ${ }^{6}$ Sedikit lebih komplek, Hadari Namawi dalam bukunya yang berjudul: "Organisasi Sekolah dan Pengelolaan Kelas" memandang kelas dari dua sudut, yaitu: pertama; Kelas dalam arti sempit yakni, ruangan yang di batasi oleh empat dinding, tempat sejumlah pembelajar berkumpul untuk mengikuti proses belajar mengajar. Kedua; Kelas dalam arti luas adalah suatu masyarakat kecil yang merupakan bagian dari masyarakat sekolah yang sebagai suatu kesatuan diorganisasi menjadi unit kerja yang secara dinamis menyelenggarakan kegiatan-kegiatan belajar mengajar yang kreatif untuk mencapai suatu tujuan. ${ }^{7}$

Suharsimi Arikunto dalam bukunya yang berjudul: "Pengelolaan Kelas dan Siswa: Sebuah Pendekatan Evaluative" mengatakan bahwa pengelolaan kelas adalah pengadministrasian, pengaturan atau penataan suatu kegiatan (secara umum) ${ }^{8}$ Jadi secara etimologi, pengelolaan kelas dapat diartikan sebagai upaya merencanakan, mengorganisir, mengarahkan, mengkoordinasi, dan mengontrol kelompok belajar yang dilakukan oleh pembelajar untuk mencapai tujuan pembelajaran. ${ }^{9}$

Adapun pengertian pengelolaan kelas secara terminology seperti yang diungkapkan oleh Wilford dalam James M. Cooper dibukunya yang berjudul: "Classroom Teaching Skills", pengelolaan kelas merupakan seperangkat perilaku yang kompleks dimana pembelajar

${ }^{6}$ Ahmad, Djauzak. Pedoman Pembinaan Profesional Guru Sekolah Dasar, (Dispendas. Bandung: Depdikbud RI, 1995), 1

${ }^{7}$ Nawawi, Hadari. Organisasi Sekolah dan Pengelolaan Kelas, (Jakarta : Penerbit PT. Haji Mas Agung, 1989), 116

8 Arikunto, Suharsimi. Pengelolaan Kelas Dan Siswa: Sebuah Pendekatan Evaluatif. (Jakarta: Penerbit Rajawali Publisher, 1988), 8

${ }^{9}$ Ibid, 8 
menggunakan untuk menata dan memelihara kondisi kelas yang akan memampukan para pembelajar mencapai tujuan pembelajaran secara efesien. ${ }^{10}$

Sedangkan Syaiful Bahri Djamarah dalam bukunya yang berjudul: "Strategi Belajar Menhgajar" mengatakan bahwa pengelolaan Kelas adalah upaya dalam mendayagunakan potensi kelas.” Kelas mempunyai peranan dan fungsi tertentu dalam menunjang keberhasilan proses interaksi edukatif, agar memberikan dorongan dan rangsangan terhadap anak didik untuk belajar, kelas harus dikelola sebaik-baiknya oleh pembelajar. ${ }^{11}$

Berdasarkan beberapa definisi tersebut dapat disimpulkan bahwa pengelolaan kelas (classroom management) adalah serangkaian tindakan yang dilakukan pembelajar dalam upaya menciptakan kondisi lingkungan pembelajaran yang positif dan produktif agar proses belajar mengajar agar dapat berjalan sesuai dengan tujuannya. Dengan kata lain, pengelolaan kelas adalah upaya memberdayakan potensi kelas melalui seperangkat keterampilan pembelajar intuk menciptakan iklim pembelajaran yang kondusif, positif, dan produktif dan mengendalikannya jika terjadi gangguan dalam pembelajaran untuk mengoptimalisasi proses pembelajaran sehingga dapat diperoleh hasil yang memuaskan.

Bertolak dari definisi tersebut, pada hakekatnya pengelolaan kelas dilakukan untuk mendukung terjadinya proses pembelajaran yang lebih berkualitas. Berikut ini beberapa hakekat pengelolaan kelas antara lain:

Pengelolaan kelas adalah serangkaian tindakan pembelajar yang ditunjukkan untuk mendorong munculnya tingkah laku yang diharapkan, menciptakan hubungan interpersonal

\footnotetext{
${ }^{10}$ Wilford A. Weber dalam James M. Cooper. Classroom teaching Skills,(Lexington : D.C. Heath and Company, 1995), 230

${ }^{11}$ Djamarah, Syaiful Bahri. Strategi Belajar Mengajar, (Jakarta: Penerbit PT Rineka Cipta, 2006), 177
} 
yang baik dan iklim sosio-emosional yang positif, serta menciptakan dan memelihara organisasi kelas yang produktif dan efektif.

\section{Tujuan Pengelolaan Kelas}

Menjadi pembelajar haruslah kaya konsep, kaya cara, dan utun (ulet) mencari varianvarian baru mengenai permasalahan di dalam kelas. ${ }^{12}$ Berbicara mengenai tujuan pengelolaan kelas, Ahmad Djauzak mengatakan bahwa tujuan pengelolaan kelas adalah sebagai berikut: Mewujudkan situasi dan kondisi kelas, baik sebagai lingkungan belajar maupun sebagai kelompok belajar yang memungkinkan pembelajar untuk mengembangkan kemampuan semaksimal mungkin. Menghilagkan berbagai hambatan yang dapat menghalangi terwujudnya interaksi belajar mengajar. Menyediakan dan mengatur fasilitas serta perabot belajar yang mendukung dan memungkinkan pembelajar belajar sesuai dengan lingkungan sosial, emosional, dan intelektual pembelajar dalam kelas. Membina dan membimbing sesuai dengan latar belakang sosial, ekonomi, budaya serta sifat-sifat individunya.

Sedangkan tujuan pengelolaan kelas menurut Sudirman (2000) pada hakikatnya terkandung dalam tujuan pendidikan. Tujuan pengelolaan kelas adalah penyediaan fasilitas bagi macam-macam kegiatan belajar pebelajar dalam lingkungan sosial, emosional, dan intelektual dalam kelas. Fasilitas yang disediakan itu memungkinkan pembelajar belajar dan bekerja. Terciptanya suasana sosial yang memberikan kepuasan, suasana disiplin, perkembangan intelektual, emosional, dan sikap serta apresiasi pada pembelajar. Sementara Arikunto (2000)

12 Ahmad, Djauzak. Pedoman Pembinaan Profesional Guru Sekolah Dasar, (Dispendas. Bandung: Depdikbud RI, 1995), 2 
Dampak Pengelola an Kelas Yang Efektif Bagi Keberhasilan Kegiatan B e lajar - Mengajar Guru Pendidikan Agama Kristen Masa Kini | 31

berpendapat bahwa tujuan pengelolaan kelas adalah agar setiap anak di kelas dapat bekerja dengan tertib sehingga segera tercapai tujuan pembelajaran secara efektif dan efesien. Degeng (2000) menyatakan bahwa tujuan pengelolaan kelas adalah agar para pebelajar dapat belajar secara optimal dan memberdayakan dirinya sesuai potensi dan karakteristiknya sendiri. ${ }^{13}$

Berdasarkan beberapa pandangan tersebut, tujuan pengelolaan kelas adalah: setiap pembelajar harus belajar, tidak macet, artinya tidak ada anak yang terhenti karena tidak tahu ada tugas yang harus dilakukan atau tidak dapat melakukan tugas yang diberikan padanya. Setiap pembelajar terus melakukan belajar tanpa membuang waktu, artinya setiap pembelajar akan bekerja secepatnya supaya lekas menyelesaikan tugas yang diberikan padanya.

\section{Pendekatan dalam Pengelolaan Kelas}

Pengelolaan kelas (classroom management) berdasarkan pendekatannya menurut Max Weber yang dikutip oleh Anitah Sri W, dkk. dalam bukunya yang berjudul: "Strategi Pembelajaran di SD” diklasifikasikan kedalam tiga pengertian, yaitu berdasarkan pendekatan otoriter (authority approach), pendekatan permisif (permissive approach) dan pendekatan modifikasi tingkah laku. Berikut dijelaskan pengertian masing-masing pendekatan tersebut:

Pertama, berdasarkan pendekatan otoriter (authority approach) pengelolaan kelas adalah kegiatan guru untuk mengontrol tingkah laku siswa, guru berperan menciptakan dan memelihara aturan kelas melalui penerapan disiplin secara ketat. Kedua, pendekatan permisif mengartikan pengelolaan kelas adalah upaya yang dilakukan oleh guru untuk memberi kebebasan kepada siswa untuk melakukan berbagai aktifitas sesuai dengan yang mereka inginkan. Dan fungsi guru adalah bagaimana menciptakan kondisi siswa merasa aman untuk melakukan aktifitas di dalam kelas. Ketiga, pendekatan modifikasi tingkah laku. Pendekatan ini didasarkan pada pengelolaan kelas merupakan proses perubahan tingkah laku, jadi pengelolaan kelas merupakan upaya untuk mengembangkan dan memfasilitasi perubahan prilku yang bersifat positif dari siswa dan

\footnotetext{
${ }^{13}$ Imam Azhar, Pengelolaan Kelas Dari Teoritis Ke Praktis, (Yogyakarta: Penerbit Insyira, 2013), 16
} 
dan berusaha semaksimal mungkin mencegah munculnya atau memperbaiki prilaku negatif yang dilakukan oleh siswa. ${ }^{14}$

Adapun macam-macam pendekatan-pendekatan lainya adalah:

1. Pendekatan Kekuasaan ${ }^{15}$

Pendekatan kekuasaan seperti yang diuraikan oleh Syaiful Bahri Djamarah adalah: guru menciptakan dan mempertahankan situasi disiplin dalam kelas. Kedisiplinan adalah kekuatan yang menuntut murid untuk mentaatinya. Di dalam kelas ada kekuasaan dan norma yang mengikat untuk ditaati anggota kelas.

2. Pendekatan Pengajaran ${ }^{16}$

Pendekatan pengajaran, pendekatan ini didasarkan atas suatu anggapan bahwa dalam perencanaan dan pelaksanaannya akan mencegah munculnya masalah tingkah laku murid dan memecahkan masalah itu bila tidak bisa dicegah.

3. Pendekatan Kerja Kelompok ${ }^{17}$

Pendekatan kerja kelompok, dalam pendekatan ini guru menciptakan kondisi - kondisi yang memungkinkan kelompok yang produktif, selain itu guru juga harus dapat menjaga kondisi itu agar tetap baik.

4. Pendekatan elektis atau pluralistic ${ }^{18}$

Ketiga pendekatan tersebut oleh guru digabungkan digunakan untuk mengelola kelas. Sehingga tercipta pendekatan elektis atau pluralistic. Menurut Djamarah Pendekatan elektis yaitu guru kelas memilih berbagai pendekatan tersebut berdasarkan situasi yang dihadapi dalam

14 Anitah Sri W, dkk. Strategi Pembelajaran di SD, (Jakarta: Penerbit Pusat Penerbitan Universitas Terbuka, 2007), 104

${ }^{15}$ Djamarah, Syaiful Bahri. Strategi Belajar Mengajar. (Jakarta: Penerbit PT Rineka Cipta, 2006), 179

${ }^{16}$ Ibid, 180

${ }^{17}$ Ibid, 182

${ }^{18} \mathrm{Ibid}, 183$ 
suatu situasi mungkin dipergunakan salah satu dan dalam situasi yang lain mungkin mengkombinasikan ketiga pendekatan tersebut.

Pendekatan elektis (electic approach) ini menekankan pada potensialitas, kreatifitas, dan inisiatif wali atau guru kelas dalam memilih berbagai pendekatan tersebut berdasarkan situasi yang dihadapinya. Penggunaan pendekatan itu dalam suatu situasi mungkin dipergunakan salah satu dan dalam situasi lain mungkin harus mengkombinasikan dan atau ketiga pendekatan tersebut. Pendekatan elektis disebut juga pendekatan pluralistik, yaitu pengelolaan kelas yang berusaha menggunakan berbagai macam pendekatan yang memiliki potensi untuk dapat menciptakan dan mempertahankan suatu kondisi memungkinkan proses belajar mengajar berjalan efektif dan efisien. Guru memilih dan menggabungkan secara bebas pendekatan tersebut sesuai dengan kemampuan dan selama maksud dan penggunaannnya untuk pengelolaan kelas disini adalah suatu set (rumpun) kegiatan guru untuk menciptakan dan mempertahankan kondisi kelas yang memberi kemungkinan proses belajar mengajar berjalan secara efektif dan efisien.

5. Pendekatan Ancaman ${ }^{19}$

Dari pendekatan ancaman atau intimidasi ini, pengelolaan kelas adalah juga sebagai suatu proses untuk mengontrol tingkah laku anak didik. Tetapi dalam mengontrol tingkah laku anak didik dilakukan dengan cara memberi ancaman, misalnya melarang, ejekan, sindiran, dan memaksa.

6. Pendekatan Resep ${ }^{20}$

Pendekatan resep (cook book) ini dilakukan dengan memberi satu daftar yang dapat menggambarkan apa yang harus dan apa yang tidak boleh dikerjakan oleh guru dalam mereaksi

${ }^{19}$ Djamarah, Syaiful Bahri, Strategi Belajar Mengajar, (Jakarta: Penerbit PT Rineka Cipta, 2006), 185

${ }^{20}$ Ibid, 187 
semua masalah atau situasi yang terjadi di kelas. Dalam daftar itu digambarkan tahap demi tahap apa yang harus dikerjakan oleh guru. Peranan guru hanyalah mengikuti petunjuk seperti yang tertulis dalam resep

7. Pendekatan Perubahan Tingkah Laku ${ }^{21}$

Sesuai dengan namanya, pengelolaan kelas diartikan sebagai suatu proses untuk mengubah tingkah laku anak didik. Peranan guru adalah mengembangkan tingkah laku anak didik yang baik, dan mencegah tingkah laku yang kurang baik. Pendekatan berdasarkan perubahan tingkah laku (behavior modification approach) ini bertolak dari sudut pandangan psikologi. Program atau kegiatan yang yang mengakibatkan timbulnya tingkah laku yang kurang baik, harus diusahakan menghindarinya sebagai penguatan negatif yang pada suatu saat akan hilang dari tingkah laku murid atau guru yang menjadi anggota kelasnya. Untuk itu, menurut pendekatan tingkah laku yang baik atau positif harus dirangsang dengan memberikan pujian atau hadiah yang menimbulkan perasaan senang atau puas. Sebaliknya, tingkah laku yang kurang baik dalam melaksanakan program kelas diberi sanksi atau hukuman yang akan menimbulkan perasaan tidak puas dan pada gilirannya tingkah laku tersebut akan dihindari.

8. Pendekatan Kebebasan ${ }^{22}$

Pengelolaan diartikan secara suatu proses untuk membantu anak didik agar merasa bebas untuk mengerjakan sesuatu kapan saja dan dimana saja. Peranan guru adalah mengusahakan semaksimal mungkin kebebasan anak didik.

\footnotetext{
${ }^{21}$ Arikunto, Suharsimi, Pengelolaan Kelas Dan Siswa: Sebuah Pendekatan Evaluatif, (Jakarta: Penerbit Rajawali Publisher, 1988), 13

22 Ahmad, Djauzak, Pedoman Pembinaan Profesional Guru Sekolah Dasar, (Dispendas. Bandung: Depdikbud RI, 1995), 7
} 
Dampak Pengelolaan Kelas Yang Efektif Bagi Keberhasilan Kegiatan Belajar - Mengajar Guru Pendidikan Agama Kristen Masa Kini 35

9. Pendekatan Sosio-Emosional ${ }^{23}$

Pendekatan sosio-emosional akan tercapai secarta maksimal apabila hubungan antar pribadi yang baik berkembang di dalam kelas. Hubungan tersebut meliputi hubungan antara guru dan murid serta hubungan antar murid. Didalam hal ini guru merupakan kunci pengembangan hubungan tersebut. Oleh karena itu seharusnya guru mengembangkan iklim kelas yang baik melalui pemeliharaan hubungan antar pribadi di kelas. Untuk terrciptanya hubungan guru dengan murid yang positif, sikap mengerti dan sikap ngayomi atau sikap melindungi.Dalam hal ini, Carl R. Rogers mengemukakan pentingnya sikap tulus dari guru (realness, genuiness, congruence); menerima dan menghargai peserta didik sebagai manusia (acceptance, prizing, caring, trust) dan mengerti dari sudut pandangan peserta didik sendiri (emphatic understanding).

\section{Strategi Pengelolaan Kelas dalam Meningkatakan Proses Belajar}

Pertama bagaimana strategi guru dalam menyusun rencana pembelajaran ${ }^{24}$ Strategi menyusun rencana pembelajaran adalah sebagai berikut kepala sekolah melalui kebijakan yang dituangkan dalam tugas guru, mewajibkan para guru untuk membuat program mengajar yang berupa: Silabus, Analisa Materi Pelajaran, Program Tahunan, Program Semester, dan Rencana Program Pembelajaran. Pembuatan program pembelajaran disusun secara bersama-sama melalui pertemuan Musyawarah Guru Mata Pelajaran yang ada di lingkungan sekolah yang selanjutnya dimantabkan melalui pertemuan Musyawarah Guru Mata Pelajaran tingkat

\footnotetext{
${ }^{23}$ Rogers, C. R, Client-Centered Counselling, (Boston USA: Penerbit Houghton-Mifflin, 1951), 108

${ }^{24}$ Amatembun, NA, Manajemen Kelas, Penuntun Bagi Guru dan Calon Guru, (Bandung: Penerbit FIP IKIP Bandung, 1989), 57
} 
Kabupaten. Selanjutnya perangkat mengajar diserahkan kepada wakil kepala sekolah bidang kurikulum untuk dikoreksi dan ditanda tangani oleh kepala sekolah. Pada saat mengajar, para guru selalu membawa perangkat pembelajaran dengan maksud agar proses belajar mengajar berjalan dengan terarah, dan tujuan yang dirumuskan dalam program bisa tercapai. Dan bila selesai mengajar perangkat mengajar disimpan di almari guru masing-masing yang telah disediakan oleh sekolah, dengan demikian bila diperlukan perangkat mengajar sudah ada di sekolah dan terjaga keamanannya.

Kedua, bagaimana strategi guru dalam membangun kerjasama dengan siswa dalam proses belajar mengajar? ${ }^{25}$ Kegiatan guru yang profesional merupakan kegiatan atau tugas guru yang rutin yang dianggap sebagai salah satu carauntuk meningkatkan profesionalismenya. Dalam menjalin kerjasama dengan siswa, strategi yang diterapkan oleh guru SMA adalah sebagai berikut: (a) menjalin hubungan baik dengan siswa, (b) berusaha memahami latar belakang siswa, (c) penguasaan materi dan cara penyajiannya menarik, (d) penggunaan model mengajar yang bervariasi dan (e) memberi pembinaan khusus bagi siswa bermasalah.

Pengembangan sekolah memiliki arti tersendiri bagi sekolah, sehingga sekolah tidak hanya menjalin kerjasama dengan siswa saja, tetapi sekolah juga menjalin kerjasama dengan orang tua/wali, perguruan tinggi, instansi pemerintah dan alumni. Adapun bentuk kerjasamanya adalah sebagai berikut: pengadaan sarana dan fasilitas sekolah, rekrutmen calon mahasiswa, penyaluran bakat dan minat siswa melalui kegiatan ektrakurikuler dan pengadaan pembina ekstra kurikuler. Kerjasama dalam hal ini, tidak hanya dilakukan melalui kegiatan pembelajaran di kelas saja, melainkan melalui kegiatan sekolah secara keseluruhan yang mengarah pada upaya peningkatan prestasi belajar siswa.

\footnotetext{
${ }^{25}$ Direktorat Dikmenum. Manajemen Peningkatan Mutu Berbasis Sekolah, Buku Konsep I dan Pelaksanaan MPMBS. (Jakarta: Penerbit Departemen Pendidikan Nasional, 2000), 135
} 
Ketiga, bagaimana pemberian motivasi belajar terhadap siswa? ${ }^{26}$ Pemberian motivasi terhadap siswa adalah sebagai berikut: (a) khususnya siswa kelas tiga selalu diberi latihanlatihan soal, (b) pemberian tugas untuk praktek lapangan, (c) mengikut sertakan siswa dalam kegiatan ilmiah, (d) mengkomunikasikan hasil belajar siswa melalui papan pengumuman maupun melalui pertemuan dengan orang tua, (e) pemberian reinforcement, (f) penggunaan media dalam pembelajaran dan (g) pemberian layanan bimbingan. Dengan pemberian motivasi dalam bentuk pemberian tugas pada siswa, hasilnya efektif sekali karena dengan strategi tersebut mampu mempertahankan dan meningkatkan prestasi belajar siswa.

Keempat, bagaimana strategi dalam menciptaan iklim pembelajaran ${ }^{27}$ Agar pelaksanaan pembelajaran di kelas berlangsung dengan lancar dan efektif, maka pihak sekolah dalam hal ini kepala sekolah, staf dan guru melakukan upaya berupa: (a) petugas tata tertib selalu mengantisipasi berkeliling di lingkungan sekolah untuk mengontrol tempat-tempat yang rawan, (b) wakil kepala kesiswaan mengadakan razia di dalam kelas dengan dibantu petugas tata tertib dan guru pembimbing, (c) dalam mengajar guru berusaha memahami karakter siswa, (d) guru berusaha menciptakan suasana pembelajaran yang demokratis, (e) guru memberi kesempatan siswa untuk bertanya tentang kesulitan pelajaran atau masalah lainnya, dan (f) guru berusaha menciptakan kemudahan siswa dalam mempelajari pelajaran eksak. Dengan strategi seperti diatas, maka iklim di lingkungan SMA, memungkinkan terciptanya lingkungan belajar yang kondusif sehingga siswa merasa senang dan betah berada di sekolah selama jam efektif kegiatan belajar mengajar, bahkan hingga sore hari untuk mengikuti kegiatan tambahan.

\footnotetext{
${ }^{26}$ Ibid, 136

27 Amatembun, NA. Manajemen Kelas, Penuntun Bagi Guru dan Calon Guru,(Bandung: Penerbit FIP IKIP Bandung, 1989), 59
} 
Kelima, bagaimana upaya dalam meningkatkan disiplin belajar siswa ${ }^{28}$ Karakteristik SMA yang baik adalah semua warganya mulai dari pimpinan sekolah, guru, karyawan dan siswanya memiliki budaya disiplin yang tinggi. Namun demikian pihak sekolah tetap mempertahankan serta melestarikan budaya disiplin yang sudah bagus ini untuk ditingkatkan menjadi menjadi kultur disiplin yang mandiri. Adapun strategi untuk meningkatkan disiplin, sebagai berikut: (a) sekolah memiliki sistem pengendalian ketertiban yang dikelola dengan baik, (b) adanya keteladanan disiplin dalam sikap dan prilaku mulai dari pimpinan sekolah, guru dan karyawan, (c) mewajibkan siswa baru untuk mengikuti ekstrakurikuler Pramuka, (d) pada awal masuk sekolah guru bersama siswa membuat kesepakatan tentang aturan kelas, (e) memperkecil kesempatan siswa untuk ijin meninggalkan kelas, (f) setiap upacara hari Senin diumumkan frekuensi pelanggaran terendah. Dengan strategi tersebut diatas kultur disiplin siswa bisa terpelihara dengan baik, suasana lingkungan belajar aman dan terkendali sehingga siswa bisa mencapai prestasi belajar yang optimal.

Keenam, bagaimana pelaksanaan evaluasi proses belajar mengajar? ${ }^{29}$ Evaluasi dalam pembelajaran di SMA ada dua macam yaitu: (1) penilaian terhadap hasil belajar siswa, (2) penilaian terhadap proses pengajaran.

Penilaian terhadap hasil belajar siswa baik dari ulangan harian, ulangan semester, Ujian Akhir Sekolah dan Ujian Akhir Nasional menunjukkan hasil yang memuaskan, berdasarkan data perolehan ulangan semester, perolehan Ujian Akhir Sekolah dan Ujian Akhir Nasional, penilaian terhadap proses pengajaran, berdasarkan hasil wawancara, observasi peneliti dan

\footnotetext{
28 Davies, I, K. Pengelolaan Belajar, Terjemahan oleh Sudarsono \& Lily, (Jakarta: Penerbit C.V. Rajawali, 1986), 51

29 Direktorat Dikmenum. Manajemen Peningkatan Mutu Berbasis Sekolah, Buku Konsep I dan Pelaksanaan MPMBS. (Jakarta: Penerbit Departemen Pendidikan Nasional, 2000), 137
} 
supervisi kepala sekolah, bahwa kompetensi guru dalam pembelajaran di kelas sudah bagus sekali, bahkan guru senior selalu menularkan etos kerja yang bagus, baik dalam melaksanakan tugas mengajarnya, tugas mengadministrasi hasil mengajar, maupun tugas tambahan dari sekolah. Keberhasilan SMA dalam mengukir prestasi juga didukung oleh: (a) input siswa yang tinggi, (b) etos kerja guru tinggi, (c) iklim sekolah yang kondusif, (d) adanya tanggung jawab moral dari guru senior untuk menularkan etos kerja yang tinggi terhadap guru baru, (e) peningkatan profesional guru melalui kegiatan Musyawaah Guru Mata Pelajaran, Diklat dan Workshop, (f) bimbingan belajar bagi semua siswa, (g) bimbingan prestasi bagi siswa peringkat 1-5 dari masing-masing kelas, (h) conversation bekerjasama dengan AMECC, dan (i) debat bahasa Inggris.

\section{Peranan Guru Dalam Pengelolaan Kelas Yang Efektif}

Pengelolaan kelas adalah keterampilan guru untuk menciptakan dan memelihara kondisi belajar yang optimal dan mengembalikannya bila terjadi gangguan dalam proses belajar mengajar. Guru dengan segala kemampuannya, siswa dengan segala latar belakang dan sifatsifat individualnya, kurikulum dengan segala komponennya, dan materi serta sumber pelajaran dengan pokok bahasannya bertemu dan berpadu dan berinteraksi di kelas. Bahkan hasil dari pendidikan dan pengajaran sangat ditentukan oleh apa yang terjadi di kelas. Oleh sebab itu sudah selayaknya kelas dikelola dengan baik, professional, dan berlangsung terus-menerus.

Pengelolaan kelas yang efektif adalah syarat bagi pengajaran yang efektif. Tugas utama dan paling sulit bagi guru adalah pengelolaan kelas, lebih-lebih tidak ada satu pun pendekatan yang dikatakan paling baik. Setiap guru masuk ke dalam kelas, maka pada saat itu pula ia menghadapi dua masalah pokok, yaitu masalah pengajaran dan masalah manajemen. Masalah 
pengajaran adalah usaha membantu anak didik dalam mencapai tujuan khusus pengajaran secara langsung, misalnya membuat satuan pembelajaran, penyajian informasi, mengajukan pertanyaan, evaluasi, dan masih banyak lagi. Sedangkan masalah manajemen adalah usaha untuk menciptakan dan mempertahankan kondisi sedemikian rupa sehingga proses belajar mengajar dapat berlangsung secara efektif dan efisien. Misalnya, memberi penguat, mengembangkan hubungan guru - anak didik, membuat aturan kelompok yang produktif. Kadang-kadang sukar untuk dapat membedakan mana masalah pengajaran dan mana masalah manajemen.

Masalah pengajaran harus diatasi dengan cara pengajaran, dan masalah pengelola kelas diatasi dengan cara pengelolaan. Pengelola kelas adalah keterampilan guru untuk menciptakan dan memelihara kondisi belajar yang optimal dan mengembalikannya bila terjadi gangguan dalam proses belajar mengajar. Yang termasuk ke dalam hal ini misalnya adalah, penghentian tingkah laku anak didik yang menyelewengkan perhatian kelas, pemberian hadiah bagi ketepatan waktu penyelesaian tugas oleh siswa, atau penetapan norma kelompok yang produktif.

Sebaliknya masalah pengelolaan berkaitan dengan usaha untuk menciptakan dan mempertahankan kondisi sedemikian rupa sehingga proses pembelajaran dapat berlangsung secara efektif dan efisien demi tercapainya tujuan pembelajaran. Dengan demikian pengelolaan kelas yang efektif adalah syarat bagi pengajaran yang efektif.

Di kelas, segala aspek pendidikan pengajaran bertemu dan berproses. Guru dengan segala kemampuannya, siswa dengan segala latar belakang dan sifat-sifat individualnya, kurikulum dengan segala komponennya, dan materi serta sumber pelajaran dengan pokok bahasannya bertemu dan berpadu dan berinteraksi di kelas. Bahkan hasil dari pendidikan dan 
Dampak Pengelolaan Kelas Yang Efektif Bagi Keberhasilan Kegiatan Belajar - Mengajar Guru Pendidikan Agama Kristen Masa Kini | 41

pengajaran sangat ditentukan oleh apa yang terjadi di kelas. Oleh sebab itu sudah selayaknya kelas dikelola dengan baik, professional, dan berlangsung terus-menerus.

Syaiful Bahri Djamarah menyebutkan "masalah yang dihadapi guru, baik pemula maupun yang sudah berpengalaman adalah pengelolaan kelas”. Hal tersebut dikarenakan bahwa dalam sutu kelas para siswa adalah merupakan makhluk social yang mempunyai latar belakang yang berbeda. Perbedaan tersebut dapat dilihat dari aspek kecerdasan, psikologis, biologis. Ketiga aspek dan tingkah laku anak didik di sekolah. ${ }^{30}$

Berangkat dari permasalahan diatas, penulis mengangkat masalah mengenai dampak pengelolaan kelas yang efektif bagi beberhasilan kegiatan belajar-mengajar guru PAK masa kiniagar guru mengetahui dan memahami tentang pentingnya pengelolaan kelas yang efektif agar keberhasilan kegiatan belajar menagajar dapat tercapai.

\section{Kesimpulan}

Pengelolaan kelas merupakan kegiatan pengaturan kelas untuk kepentingan pengajaran. Pengelolaan kelas bertujuan menyediakan fasilitas bagi bermacam-macam kegiatan belajar siswa dalam lingkungan social, emosional, dan intelektual dalam kelas. Agar dapat mengelola kelas secara efektif perlu memperhatikan hal-hal sebagai berikut: (1) Kelas adalah kelompok kerja yang diorganisasi untuk tujuan tertentu,yang dilengkapi oleh tugas-tugas dan diarahkan oleh guru. (2) Dalam situasi kelas, guru bukan tutor untuk satu pada waktu tertentu, tetapi bagi semua anak atau kelompok. (3) Kelompok mempunyai perilaku sendiri yang berbeda dengan perilaku-perilaku masing-masing individu dalam kelompok itu. (4) Kelompok kelas

\footnotetext{
${ }^{30}$ Djamarah, Syaiful Bahri. Strategi Belajar Mengajar, (Jakarta: Penerbit PT Rineka Cipta, 2006), 185
} 
menyisipkan pengaruhnya kepada anggota-anggota. (5) Praktik guru waktu belajar cendrung terpusat pada hubungan guru dan siswa. (6) Struktur kelompok, pola komunikasi, dan kesatuan kelompok ditentukan oleh cara mengelola, baik untuk mereka yang tertarik pada sekolah maupun bagi mereka yang apatis, masa bodoh atau bermusuhan. 


\section{DAFTAR PUSTAKA}

Ahmad, Djauzak. Pedoman Pembinaan Profesional Guru Sekolah Dasar. Dispendas. Bandung: Depdikbud RI, 1995.

Amatembun, NA. Manajemen Kelas, Penuntun Bagi Guru dan Calon Guru. Bandung: Penerbit FIP IKIP Bandung, 1989.

Anitah Sri W, dkk. Strategi Pembelajaran di SD. Jakarta: Penerbit Pusat Penerbitan Universitas Terbuka, 2007.

Arikunto, Suharsimi. Pengelolaan Kelas Dan Siswa: Sebuah Pendekatan Evaluatif. Jakarta: Penerbit Rajawali Publisher, 1988.

Davies, I, K. Pengelolaan Belajar. Terjemahan oleh Sudarsono \& Lily. Jakarta: Penerbit C.V. Rajawali, 1986.

Direktorat Dikmenum. Manajemen Peningkatan Mutu Berbasis Sekolah, Buku Konsep I dan Pelaksanaan MPMBS. Jakarta: Penerbit Departemen Pendidikan Nasional, 2000.

Djamarah, Syaiful Bahri. Strategi Belajar Mengajar. Jakarta: Penerbit PT Rineka Cipta, 2006.

Hamalik, Oemar. Manajemen Pendidikan dan Pelatihan. Bandung: Penerbit Y.P Pemindo, 2000.

http://rahayuzaini.blogspot.co.id/2016/03/pengelolaan-kelas-dalam-pembelajaran.html

Imam Azhar. Pengelolaan Kelas Dari Teoritis Ke Praktis. Yogyakarta: Penerbit Insyira, 2013.

Ketut Arya Sunu, I Gusti. Manajemen Kelas. Yogyakarta: Penerbit Media Akademi, 2015

Nawawi, Hadari. Organisasi Sekolah dan Pengelolaan Kelas. Jakarta: Penerbit PT. Haji Mas Agung, 1989.

Rogers, C. R. Client-Centered Counselling. Boston USA: Penerbit Houghton-Mifflin, 1951. 
Wilford A. Weber dalam James M. Cooper. Classroom teaching Skills. Lexington: D.C. Heath and Company, 1995. 